\title{
Denmark a Nordic Welfare State - Are the Active Labour Market Policy Withering Away?
}

\author{
Bent Greve*
}

Department of Society and Globalisation, Roskilde University, Denmark

\begin{abstract}
Denmark has been portrayed as a country with a focus on full employment, gender equality and high level of participation on the labour market. It has historically further been built upon consensus and class-compromises and known for flexi-curity. The active labour market policy has focused on how to ensure not only a work-first approach, but that a constant upgrading of qualifications would guarantee that the individual citizen could have the qualification to enter and to stay on the labour market.

A core question is whether the focus on flexi-curity including upgrading of skills and integration on the labour market has been withering away towards a sharper focus on a work first approach, where activation is used as a stick more than a carrot, also implying that rights' as citizens has been increasingly reduced, and, thereby increased the role of citizens as labourer on the labour market.

The article concludes, based on a detailed case-analysis of Denmark, that profound changes has taken place over the last 10-15 years implying that the active labour market policy has strengthened its focus on work-first. Access to benefits has moved in a less citizen based direction, and the principles of universality and generosity of benefits has been gradually eroded. Furthermore, that the social partner's role has been reduced among other things also due to lower union density rates. A short comparison with the other Nordic countries is used as a background for depicting the changes. However, by the end of 2011 a few changes perhaps marking a shift towards a human-capital approach has taken place.
\end{abstract}

Keywords: Work-first, welfare states, Nordic Welfare Model, Denmark, Active labour market policy.

\section{INTRODUCTION}

Denmark, and, the other the Nordic Welfare States to varying degrees, are depicted as universal welfare state systems based upon citizenship with relatively generous welfare benefits, high degree of equality including gender equality and a focus on full-employment [1]. The Nordic welfare states have also been described as having a focus on full-employment and an active labour market policy. In Sweden the active labour market policy started to expand already late in the fifties [2] inspired by the trade union economist Rehn and Meidner. Active labour market policy is thus not a complete new element in the Nordic welfare states, but has a long history with focus on full employment and equality in access to the labour market and in income distribution. Welfare policies also have a long tradition, at least in Denmark since the Kanslergade-agreement in 1933, to be based upon broad political consensus between workers and farmers.

Focus on the labour market also explains why flexi-curity has been in place in the Nordic countries even before it became famous in the European Union. The Nordic welfare states have thus for a long time followed the definition of flexicurity:

*Address correspondence to this author at the Department of Society and Globalisation, University of Roskilde, Denmark,

Tel: 0045 46742585/22958814; Fax 0045 46743080; E-mail: bgr@ruc.dk
A policy strategy that attempts synchronically and in a deliberate way, to enhance the flexibility of labour markets, work organisation and labour relations on the one hand, and to enhance security - employment security and social security - notably for weaker groups in and outside the labour market, on the other hand' [3].

This article proceeds by first arguing for ways to understand what active labour market policy is, and, how this can be combined with a Marshallian understanding of citizenship [4]. This section will be followed by a short quantitative presentation of how the Nordic countries has changed position mainly when comparing central data related to the labour markets and spending on social protection. Then it will be analysed, by using the caseapproach method, with Denmark as a reference case, how the graduate change in activation policy has taken place, and, by this also show that what at first sight can look like pathdependency is presumably not a critical juncture, but a dramatic change of the path by gradually and slowly implemented change in a universal welfare state. Welfare state literature thus needs to be more aware of the impact of seemingly small incremental change in welfare states, e.g. even if in principle the basic construction seems still to be there, core changes might have taken place. The article thus being in line with the understanding that incremental changes will and can imply institutional change [5]. The combination of quantitative data used for a short comparison of the Nordic countries with EU/OECD countries and a more in depth analysis of the how the Danish system has evolved 
leads to a conclusion of changes in the Danish labour market policy, and by this implicitly also the welfare state.

The article will not explore the possible consequences in other areas of the Danish or other Nordic welfare states; such as that being on the labour market increasingly implies a division in access to welfare [6]. The change is most profound in the area of pension where being on the labour market has a substantial impact on the access to high levels of disposable income also after retiring. The use of occupational welfare can be understood as a diminishing of the the universalistic approach in the Nordic countries, and, thereby also a reduction in the use of the principle of citizenship.

Finally, the article offers some conclusion on how to grasp development in the Danish welfare state and labour market policy including whether the activation has changed from one type to another type of activation.

\section{ACTIVE LABOUR MARKET POLICY}

Active Labour Market Policy (ALMP) has been central in the EU-employment strategy since at the least the Luxembourg Summit and guidelines on employment policy in December 1997. Still, for many years evaluation of ALMP has at best been inconclusive on the effectiveness of the policy [7]. However, in times of recession education might be effective [8]. Despite the often negative interpretation of the impact of active labour market policy this is still a central issue in Denmark, which might be explained by specifically the historical use hereof, and that retrenchment is more difficult if the level of unemployment is a policy issue, which is has often been in all the Nordic countries in line with the commitment to full employment.

A core issue is whether the rhetoric of active labour market policy has the same understanding and implication in all cases. However, firstly it is necessary to discuss what active labour market policy is. The core argument for implementing ALMP is that market fails, e.g. without intervention there will not be a balance between supply and demand for labour. The main reason for this relates to lack of transparency among the different markets, a possible rigid wage structure and a low level of investment in employability. Classical understanding of labour market theory would argue that the markets left to itself would clear if people were willing to accept the on-going wage rate, which also implies a risk of hysteresis, e.g. that unemployment do not affect the real wage rate [9]. Activation is often related to the right to receive benefits and the conditions attached to receiving these benefits, e.g. to a high degree the relation between rights and duties.

The active labour market policy thus focus on how to redress these market failures, and, therefore both in the EUstatistics and OECD discussion on ALMP, cf. for example various years of OECD's publications Employment Outlook, focus is on:

Employment incentives, training, integration of disabled people, direct job creating and start-up incentives.

Various types of instruments is thus available for active labour market policy, and, the question is how and to what extent they are used to increase human capital and employability instead of focusing on a work-first approach. Affordable and high quality day care as in the European employment strategy also have an impact on the participation level, especially for women, and thus also be part of the active labour market policy, e.g. points to the discussion on whether child care should be seen as an expenditure or social investment [10]. In the Nordic countries childcare is universal and well developed, and will therefore not be further included in the analysis.

The interventions, as mentioned above, should then imply and help in ensuring a better match between demand and supply and also that the time-spell of unemployment is relatively short. Several of these initiatives have been part of the active labour market policy at the least for the last 30-40 years. The relation between unemployment and benefits might be that the stick (e.g. reducing or taking away benefits) is the most central element working in the active labour market policy, more than the carrot of getting better qualifications and becoming an insider at the labour market. The motivation effect (or threat effect) can be part of the understanding of why and how active labour market policies have changed in recent years. It is also important to look into the link between unemployment protection and activation [11].

In order to comprehend the relation between benefits and activation an understanding of different types of activation is needed. Referring back also to Esping-Andersens typology of welfare states the aspect of de-commodification could lead to a belief that the main focus of activation would be not to help to commodify the individual. This due to that the Nordic countries where seen as highly decommodifying. Despite this, the ambition of active labour market policy to a certain degree has been to ensure social inclusion [12], although social inclusion also often implies a degree of social exclusion. A question is whether the focus has been on commodifying or inclusion and what types of welfare to work regimes, as described by Dean, has been used. The focus by Dean was a typology with four different types of welfare to work regimes [13]:

Human Capital Development (egalitarian and competitive in focus)

Coercive - work first (authoritarian and competitive in focus).

\section{Active Job Creation (egalitarian and inclusive in focus)}

Insertion/right to work (authoritarian and inclusive in focus).

This typology is using as a structuring device for evaluation of the labour market policy, cf. appendix 3 . Denmark and the other Nordic welfare states, at least in a historical perspective, were mainly focusing on the active job creation having the implicit ethical stance of trying to make societies more equal and also help to make inclusion more effective. Part of this stems from an early understanding of an active society [14]. Here the public sectors direct employment impact as part of an active labour market policy will not be included in the analysis, but the public sector policy has in most countries since the end of the $20^{\text {th }}$ century been less focusing on using the public sector in the employment strategy [13]. Still, as part of an economic 
Table 1. Ranking of Nordic Countries Based Upon Core Parameters in Selected Years

\begin{tabular}{|c|c|c|c|c|c|c|c|c|c|c|c|c|}
\hline \multirow[b]{2}{*}{ Area/Year } & \multicolumn{3}{|c|}{ Denmark } & \multicolumn{3}{|c|}{ Finland } & \multicolumn{3}{|c|}{ Norway } & \multicolumn{3}{|c|}{ Sweden } \\
\hline & 1994 & 2007 & 2010 & 1994 & 2007 & 2010 & 1994 & 2007 & 2010 & 1994 & 2007 & 2010 \\
\hline Unemployment $(1998,2002)$ & 12 & 9 & 10 & 27 & 21 & 16 & 8 & 6 & 1 & 19 & 15 & 18 \\
\hline $\begin{array}{l}\text { Incidence of Long-term unemployment } \\
\text { rate } 12 \text { months and over }\end{array}$ & 9 & 9 & 8 & .. & 10 & 9 & 7 & 5 & 4 & 6 & 7 & 6 \\
\hline Labour Force Participation Rate (2006) & 3 & 4 & 3 & 11 & 12 & 12 & 6 & 5 & 5 & 2 & 3 & 3 \\
\hline $\begin{array}{l}\text { Labour Force Participation Rate Women } \\
\qquad(2006)\end{array}$ & 3 & 3 & 3 & 6 & 6 & 8 & 4 & 4 & 5 & 2 & 2 & 2 \\
\hline $\begin{array}{l}\text { Labour Force Participation rate 55-64 } \\
\text { years }\end{array}$ & 3 & 4 & 6 & 10 & 10 & 9 & .. & 2 & 3 & 2 & 1 & 2 \\
\hline Gender wage gap (1998 and 2009) & 5 & .. & 3 & 10 & .. & 19 & 4 & .. & 3 & 9 & .. & 13 \\
\hline
\end{tabular}

Source: Calculated based upon absolute data for unemployment, employment Rate, long-term unemployment rate, gender wage gap (OECD Employment Outlook, 2011), which therefore also is a ranking including all OECD countries (in most years 34, gender gap although maximum 27) where data is available in the years used.

Note: The changed position regarding gender wage gap is influenced by more countries in 2009 than in 1998. Years in bracket indicates deviation of years from the year shown at the top of the table.

demand-management policy public sector employment and public sector investment can be central, also given that being on the labour market, even in supported employment, in times of lack of demand will make it easier to be included in a job when recession is over.

This relation between the understanding of a welfare state and activation also points to that the Nordic welfare model would have comprehensive and generous unemployment benefits, focus on integration and full employment and an egalitarian approach including the use of Keynesian demand management [15]. Activation can be understood in various ways. One way, in which the Nordic welfare states seemingly is moving towards is that activation is "the introduction of an increased and explicit linkage between on the one hand, social protection, and on the other hand, labour market participation and labour market programmes" [16].

The question is whether Denmark has moved away from the human capital approach (Deans first typology) of active labour market policy towards a more authoritarian view (Deans second) where work first is the main priority and with less emphasis on human capital development and social inclusion as in the third group. This also includes whether the commitment in the system continuously is to guarantee a decent minimum income also for those outside the labour market.

\section{A SHORT REFERENCE BACKGROUND}

This section provides shortly a background by presenting the Nordic countries in a comparative framework.

Given that Denmark and the other Nordic welfare states position has been seen as countries with full employment, a high degree of gender equality and an active labour market policy the following will try to empirically indicate whether this is still the case, or whether the position has changed over the last 10-15 years for the Nordic countries. This will be done by a comparison of the ranking of the Nordic countries (in Table 1) in relation to participation rate (for all, for women and for elderly workers), unemployment (yearly and long-term) and the gender pay gap where the reference is the OECD countries. In Table 2 spending on social protection as percentages of GDP, spending on active and passive labour market policy and participation in education and training where the reference is EU countries and Norway. Ranking is used instead of the exact figures (although the exact figures are provided as references in Appendix 1 and 2), as change in ranking position can be understood as deviation from the relative position the countries have had, although the reason for deviation might not only be in the countries in consideration, but given the focus is on change compared to other this is a reasonable approach, also especially given that this is, for the Danish case, followed up by a presentation of core changes in the labour market policy in the last 10 years.

Table 1 shows that Denmark and the Nordic welfare states with regard to labour market data no longer is as distinct as they used to be, although there is still in several areas a clear profile of the Nordic countries. This is the case with regard to the ability to reduce or avoid long-term unemployment. The labour force participation rate for women and the elderly is also among the best in the OECDarea, and has increased in absolute terms as well. The ability for both men and women to be on the labour market and thereby gender equality in access to the labour market seems to prevail. Unemployment is albeit an example of an area where the Nordic countries do not seem to be distinct any longer (exception being Norway), and the absolute level, cf. appendix, changes with changes in business environment. The Nordic countries have neither, with Norway and Denmark being exceptions, a clear profile in relation to ensuring that equality in wage is achieved. Finland and Sweden have all been moving to some of those with a high level of inequality, although the rank is influenced by the number of countries involved in the analysis.

In Table 2 the ranking on social spending and labour market spending and participation in training is shown. Spending on active labour market policy still shows a clear commitment in Denmark and Sweden, less so in Finland and Norway. Norway's position can be explained by the low level of unemployment. This also explains Norway's position with regard to spending on passive labour market measures. Still, it is in general an indication of that the Nordic countries have the same position as earlier, although Sweden has remarkably reduced spending on passive labour market policy. Nordic countries spend in general more on social protection, Norway again an exception, than other 
Table 2. Ranking of Nordic Countries Based Upon Spending on Social Protection and Labour Market Policy

\begin{tabular}{|c|c|c|c|c|c|c|c|c|c|c|c|c|}
\hline \multirow[b]{2}{*}{ Area/Year } & \multicolumn{3}{|c|}{ Denmark } & \multicolumn{3}{|c|}{ Finland } & \multicolumn{3}{|c|}{ Norway } & \multicolumn{3}{|c|}{ Sweden } \\
\hline & 1999 & 2005 & 2010 & 1999 & 2005 & 2010 & 1999 & 2005 & 2010 & 1999 & 2005 & 2010 \\
\hline $\begin{array}{l}\text { Public Social Protection } \\
\text { Expenditure (2009) }\end{array}$ & 3 & 2 & 1 & 11 & 7 & 8 & 9 & 11 & 14 & 1 & 1 & 3 \\
\hline $\begin{array}{l}\text { Spending on active labour } \\
\text { market policy }\end{array}$ & 3 & 3 & 1 & 10 & 17 & 8 & 7 & 9 & 13 & 2 & 1 & 5 \\
\hline $\begin{array}{l}\text { Spending on passive labour } \\
\text { market policy }\end{array}$ & 1 & 2 & 6 & 3 & 4 & 3 & 14 & 13 & 21 & 6 & 9 & 14 \\
\hline $\begin{array}{l}\text { Percentages of the } 25 / 64 \\
\text { years of age participating in } \\
\text { education/training (2003) }\end{array}$ & 2 & 2 & 1 & 3 & 3 & 3 & .. & 5 & 5 & 1 & 4 & 2 \\
\hline
\end{tabular}

Source: Eurostat online database. Eg. for most years covering the 27 member states + Norway in total 28 countries.

Note: Years in bracket indicates deviation of years from the year shown at the top of the table.

European countries, also in absolute terms has there been increase since 1999, cf. Annex 2. Participation in training and education is also higher in the Nordic countries than in the other EU-member states.

Looking specifically on Denmark, Denmark is doing well in relation to labour market participation, spending on active and passive labour market policy and also as being able to reduce long-term unemployment, but less so with regard to the level of unemployment. The level of training is also high.

Even if the position has changed in some areas this could in principle be both due to catching up from other EU countries and reduction in the approach of Denmark and the other Nordic countries. In relation to the participation at the labour market this is seemingly the case as all EU-countries has focused on increased participation at the labour market. The Nordic active labour market policy no longer seems to be so effective as it used to be at least when looking at the position with regard to the level of unemployment. The decline in the position on inequality in wages between men and women is also a reminder of that the distinctness of the Nordic model has at least to at certain extend been reduced over the last years.

A possible explanation for that such profound change can have taken place might be that the trade unions have been weakened substantially in several of the Nordic countries [17]. However, membership still remains high compared to other OECD-countries. In Denmark the trade union density fell from 74.9 in 1999 to $67.6 \%$ in 2008 and in Sweden it has been even more dramatic from 80.6 to $68.3 \%$ [18]. So in line with declining trade-union density the ability to tighten and change the active labour market policy from an allencompassing policy to having a higher focus on just activation and a coercive focus might have taken place, cf. also the specific analysis of the Danish case. In the coming years the density rate might be further reduced in Denmark as the tax-rebate for the payment to trade-unions has been reduced from the $1^{\text {st }}$ of January, 2011.

Recent attempts from various think-thanks to rank countries also on measures including well-being and happiness seems to confirm that the Nordic countries although still rank high in international comparisons [19], and likewise Denmark is often depicted as one of the world's most happy people and nation.

\section{THE DANISH CASE - FROM ONE TYPE OF ACTIVATION TO ANOTHER?}

This section will analyse whether there has been a systematic change in activation from what was labelled an active job creation including focus on human capital towards a more authoritarian approach where a work first or right to work has been more in focus. The way this will be done is by presenting changes in the Danish labour market policy over the last approximately 10 years and show how gradual the system has been, at the least, recalibrated.

Active labour market policy in Denmark has been at play since the establishment of unemployment insurance in the early $20^{\text {th }}$ century with a demand for actively searching job to be able to receive unemployment benefit, through Keynesian demand management by public works in the thirties and early seventies and development of a labour market education system since the 1950's. Despite this what often is considered as the more systematic approach to ALMP is from late seventies in the wake of the high unemployment rate after the $1^{\text {st }}$ and $2^{\text {nd }}$ oil-price-shock with ambition to activate especially young people. The expectation was that the ALMP should bridge the gap until the economy went back to "normal" growth rates. This was further in line with the historical approach in the Danish labour movement of having both rights and duties although the unemployment benefit system was made close to that it could be received over a full working life. By the enactment of the labour market reform in 1994 this was tightened, but this was done and accepted by the trade unions due to the promise of an economic policy moving towards fullemployment. Hereafter there was a division of the unemployment insurance period between a passive and an active period [20]. Still, although rights and duties has been central historically this became even more profound in the wake of the reforms in the nineties, and also with a more clear focus in the social assistance system of a duty to work. Tightening of and restriction on the unemployed thus started in the nineties, but as we will be further explained later and can also be seen in Appendix 3, this were more profound after the liberal led government took over in 2001.

Due to the increased focus on activation and a so called kick-start of the economy it was possible in the nineties to reduce the length where the individual could receive 
unemployment benefit without this having a negative impact on individuals' living standard as the level of unemployment were falling in most of the years since the Social-Democratic led government took over in 1992. The main focus and aim was to try to get as many people as possible back on the labour market by upgrading employability in the "active period" back to the labour market and by this also be integrated into society. The relative success of the economic policy helps in explaining why relatively profound changes were possible without any dramatic conflict with the trade unions.

Furthermore, for those not able to work fulltime new measures were taken. This was, as a prime example, the aim of the flex-job system. This, as the flex-job system in Denmark makes it possible to work fewer hours and for the employers to receive an employment subsidy from the state. The target group for this ALMP has been those at risk of leaving the labour market completely, and, thereby been a vulnerable group at the border of the labour market. A core requirement to be fulfilled before being eligible for a flexjob is that all possibilities for vocational rehabilitation, work testing and transfer to other types of work in unsubsidized employment have been exhausted. All other types of activation should have been tried before the local municipality can offer a flex-job. A private employer will be reimbursed between $1 / 2$ and $2 / 3$ of the wage costs. Flex-jobs are thus positions under specific condition made to persons who have a considerable and permanent reduction in their capacity to work under ordinary conditions in the labour market. The flex-job system has created a more capacious labour market. The cost although being 7.3 billion Danish Kroner on the budget for 2009 [21]. There has been a large increase in the number of persons on flex-jobs and also on early retirement pensions in Denmark so that from 2003 to 2010 it has increased from around 275.000 to around 315.000 persons (in both cases calculated on full persons on a yearly basis). This is despite that the reform in December, 2000 which aimed at creating a more flexible labour market (through flex-jobs), but at the same time with an expectation that fewer persons would get early retirement pension. The former liberal led government has in October, 2010 argued for a reform of the scheme as they see it to beneficial and costly comparing to the outcome of the activities [22], which is in contrast to how it was described just a few years earlier: "there has been a comfortable increase in jobs with special consideration to the employees' particular needs" [23].

Although focus here is on the active part of the labour market policy this needs to be seen in the light of strategies related to receiving passive benefits (such as unemployment benefits and social assistance), also given that the generosity of benefits have an impact on the understanding of whether Denmark are still pursuing a distinct model.

Change in the level of benefit is an indicator of such changes away from the universal generosity. This has been changed not by direct policy intervention, but mainly by policy by default. Regulation of income transfers in Denmark use an index following wage development, although if above a threshold of $2.0 \%$ a level of $0.3 \%$ will be deducted to a fund, which then will have to be used for social purposes. The implication has been that income transfers in most areas have neither been able to keep the buying power, nor follow the development in real income on the labour market.

The replacement rate as used historically has shown high replacement rates in 1980 for Denmark(81.8) and Sweden (82.0), but low in Finland ( 34.4) [24], and also data for 1989-1994 shows a high rate for both Denmark (90) and Sweden (80), with Norway (65) and Finland (63) lower [25]. In the middle of the nineties the Nordic countries ranked for gross-unemployment benefit for a single person in the first year among OECD countries (Sweden 1, Denmark 2, Finland 5 and Norway 8), however the replacement has dropped to 76 in Sweden and 71 in Denmark. Replacement rates are slightly higher when taking the impact of the taxsystem into consideration. For Denmark the long term trend looking at a summary of benefit entitlements increase from 1960 to late seventies, and, then a standstill until early nineties, but then declining [26]. From 2001 and to 2008 the net replacement rate can based upon OECD's dataset on taxes and benefits be calculated to have further declined from 63.8 to 60.9 . The decline in coverage has been made not only through the lower gradual increase in the benefit, but also due to a change in the tax-system that from 2004 introduced a in work tax allowances at $2.5 \%$ of the labour income with a maximum of 6000 Danish Kroner. A special in work tax allowances is thus another way to reduce the netreplacement rate of unemployment benefits. The in-work tax-allowances have since been increased to $4.0 \%$ ( $\max$ 12.300 D.Kr.) in 2008 and $4.25 \%(\max 13.600)$ in 2010. This implies a further reduction in the tax on employed compared to the unemployed. This kind of changes is in accordance with the understanding of making hidden changes in the welfare states [27]. It shows a gradual reduction of buying power, which also in the longer run might weaken trade unions as they also recruit members due to their administration of the state decided unemployment insurance system.

The overall implication of the described development has been a gradual reduction of the generosity of unemployment benefit and social assistance over the last 10-15 years. The social implication of unemployment and risk of living in poverty if outside the labour market for longer time span has thus increased considerably over the years.

A further important aspect that has moved the Danish model away from its distinct features has been the tightening of the conditions and time for receiving unemployment benefits, and, also social assistance has been changed and for some even reduced in recent years, cf. also the overview in Appendix 3. The reduction especially of the level of social assistance and tightening of conditions to receive if, $\mathrm{cf}$. the demand for hours to work in order to continuously to receive social assistance, lower level for the under 25 years of age and ceiling after 6 months shows a continuously reduction and tightening of rights to benefits.

The change in the spring of 2010 which lowered the length of time unemployment benefit could be received from four to two years by the $1^{\text {st }}$ of July, 2012, and at the same time it changed the way how to be able to continue to have unemployment benefit [28] has as a consequence that the income security in the Danish flexi-curity model has been dramatically reduced. There is further a duty to work, although in the beginning not all types of work, and also 
rapidly to be in activation, and even activation without a clear educational purpose.

The above-mentioned reduction from four to two years is not, in a comparative perspective, implying a low level of coverage. However, the changes implies that there is a risk that more people will leave the labour force, and, thereby not be available when more labour force is needed, as the expectation is that there will be, in a few years' time, many civil servants which will be retiring. This risk has been increased due to that the number of weeks where the individual will have to be fully employed will be increased from 26 weeks to 52 weeks within a three years period. Those on the margin of the labour market will have difficulties in fulfilling this demand. The implication being that they might move even further away from the labour market. This change has also been made despite criticism from the trade unions, and, thus a further indication of a reduction in their influence in the Nordic welfare states. It also emphasize that despite large welfare reforms, such as the reform in 2006, normally has been decided by a broad majority of parties, there has increasingly been a more narrow majority changing often in the agreement of the finance bill between the liberals, the conservative and the Danish peoples party, implying a clear movement towards a more liberal stance in welfare policies, with health care and support for the elderly as exceptions.

Education has further been reduced as part of the active labour market policy and this will have a risk of being especially a problem for the low skilled. Low skilled are further a group with a higher risk of losing jobs even when the economic situation again becomes more favourable, as all analysis points to that fewer jobs will be to the unskilled [29].

The main argument for the changes has been that more people will actively search for a job when in risk of not receiving unemployment benefit, also due to that social assistance is means-tested also against a possible spouse income and wealth, whereas unemployment benefit is "only" dependent on that the social contingency occurs. This is combined with the so called threat-effect of activation is seen as part of the success for the Danish labour market policy, but has also called for a criticism of the way the active labour market policy is implemented. The changes of activation from a state led system where the partners had a central role to a decentralised system by the municipalities, albeit with many central rules has again weakened the labour market partners [30]. The threat effect was also the argument used in 2010 when the time for receiving unemployment benefit was reduced from 4 years to 2 years [31]. This is in general due to that focus seemingly has been more on the stick than the carrot effect of active labour market policies, and, also implicitly mistrust in that the active classical labour market policy with focus on education, training and jobplacement is effective. In 2011 a new agreement reducing the length of early retirement benefit and later option (in the future varying depending on the average life-expectancy, e.g. it is expected to increase automatically) for receiving early retirement. This again is a move towards a stronger focus on work and later retirement from the labour market.

Looking through the many and varied changes as depicted in Appendix 3 thus shows that focus on work-first has become more prominent and also that the pressure on the unemployed stronger than it has used to be. Tighter criteria for receiving benefits combined with a gradual lowering of the benefits, and, a less strong integration of the labour market partners in policy making has changed the Danish labour market model without this be witnessed by one of the many changes, but the sum of all changes has implied a distinct movement in the Danish labour market model towards more coercion and less inclusion. A continuous debate has therefore also been on whether activation is mainly focussing on pushing people back or giving people options and support in relation to retirement from the labour market.

The understanding of what welfare policies in Denmark are has further been blurred by that debate on the impact of migration and migrants workers. The last ten years has seen tightening of conditions for foreigners and lower level of benefits (start-help), as part of right wing led policy against migrants in Denmark, where the liberal led government has been dependent on the Danish peoples party who has constantly argued for more tight rules in relation to welfare benefit for migrants and for restriction in order to come to Denmark. The incoming government in October, 2011 promised in the election campaign to abolish the start-help and did so from 1 st of January, 2012.

At the same time, the Danish labour market policy still has an emphasis on how to integrate, and Denmark, for example in a comparison with 8 other European countries seemed to have the largest spending on integration of disabled into the labour market, and, where also among those with the highest employment rate for disabled people, and that the difference between rights based, obligation based or incentives based seemed not to have an impact [32].

\section{CONCLUSIONS}

Denmark has moved towards a clearer focus on a workfirst approach and has also reduced the impact on and consequences of universalism and citizenship in favour of an approach where the stick in labour market policy has a more profound role than earlier. Active labour market policy thus to a lesser degree than before have a focus on upgrading of human capital and a higher focus on as fast as possible to return to the labour market. Rights and duties are now even more than earlier part of the welfare systems, granting this have in fact been a cornerstone of the Nordic labour movement right from the beginning, and, therefore it has been rediscovered [33]. The thought that the people believe in the model, and, that this by shaping goals and beliefs should imply a path-dependency of the Nordic model [34] can therefore also be questioned. The path seems more and more to deviate towards a new kind of welfare model and this can only be witnessed by having a long-time perspective in the analysis and evaluation of changes.

This conclusion is based upon that the requirements for receiving unemployment benefit or social assistance has been tightened over the last years and an increased focus has been on being on the labour market. Still, there have also been other tendencies, such as the flex-job in Denmark, which is an instrument that implies an opportunity for people to continue working on the labour market at the on-going wage-rate with a public subsidy in so many hours they are able to work. 
This further implies that if citizenship in Marshalls understanding implies full membership of a community then the Nordic models has moved slightly away from this due to that focus is now even more than before on activation first, and development of human capital next [35]. Furthermore, the gradual reduction in the replacement rate for unemployed people (both on unemployment benefit and social assistance) has as implication that the living standards between insiders and outsiders in relation to the labour market has changed in disfavour to the outsiders. By this the Nordic countries have moved more towards a European type of social model. The reduced density rate for trade union membership combined with less integration of the partners in the decision making can have further long-term impact on the Danish labour market policy, which might move it even more towards a work-first approach than what was the original intention of the model. The classical consensus style decision making has therefore also been undermined in recent years, which although might change with the new government, implying especially that the role of the labour market partners has been weakened [36].

With the incoming government in October, 2011 the emphasis has been a slight shift towards more focus on education. However, given the budget constraints due to the financial crisis the changes are still only more limited, and, the government accepted the previous government on reform of the early retirement scheme implying a later retirement from the labour market. Still, a slight change has occurred that might imply a movement away from coercion to focus on human capital.

Appendix 1. Absolute Data for Nordic Countries Used in the Ranking in Table 1

\begin{tabular}{|c|c|c|c|c|c|c|c|c|c|c|c|c|}
\hline Area/Year & \multicolumn{3}{|c|}{ Denmark } & \multicolumn{3}{|c|}{ Finland } & \multicolumn{3}{|c|}{ Norway } & \multicolumn{3}{|c|}{ Sweden } \\
\hline Unemployment rate $(1998,2002)$ & 4.9 & 7.3 & 6.7 & 11.4 & 9.1 & 8.4 & 3.1 & 3.7 & 3.5 & 8.2 & 6.0 & 8.4 \\
\hline $\begin{array}{l}\text { Incidence of Long-term unemployment rate } \\
12 \text { months and over }\end{array}$ & 32.1 & 16.2 & 19.1 & .. & 23.0 & 23.6 & 28.8 & 8.8 & 9.5 & 25.7 & 13.0 & 16.0 \\
\hline Labour Force Participation rate 55-64 years & 53.7 & 60.8 & 61.1 & 41.3 & 58.8 & 60.2 & 63.2 & 69.7 & 69.6 & 66.5 & 73.0 & 74.6 \\
\hline Gender wage gap \% (1998 and 2009) & 15 & .. & 9 & 22 & .. & 20 & 10 & .. & 9 & 17 & .. & 15 \\
\hline
\end{tabular}

Source: Calculated based upon absolute data for unemployment, employment Rate, long-term unemployment rate, gender wage gap (OECD Employment Outlook, 2011), which therefore also is a ranking including all OECD countries (in most years 34, gender gap although maximum 27) where data is available in the years used.

Note: The changed position regarding gender wage gap is influenced by more countries in 2009 than in 1998. Years in bracket indicates deviation of years from the year shown at the top of the table.

Appendix 2. Absolute Data for Nordic Countries Used in the Ranking in Table 2

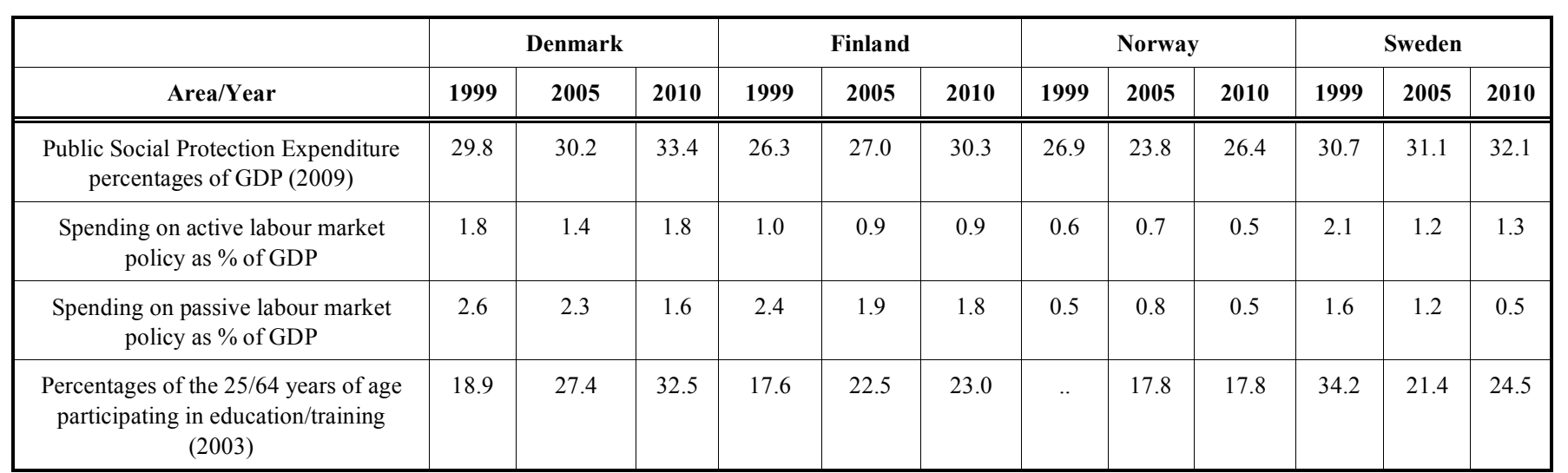

Source: Eurostat online database. Eg. For most years covering the 27 member states+ Norway in total 28 countries.

Note: Years in bracket indicates deviation of years from the year shown at the top of the table.

Appendix 3. Reforms of Activation and social Assistance and Start Help, 2002-2011

\begin{tabular}{|c|r|c|}
\hline $\begin{array}{c}\text { Year } \\
\text { Reform }\end{array}$ & Principal Measures & $\begin{array}{c}\text { Programmatic } \\
\text { Orientation }\end{array}$ \\
\hline \hline $\begin{array}{c}2002 \\
\text { Start help }\end{array}$ & $\begin{array}{c}\text { New social assistance benefit, start help, for persons who have not lived in Denmark } \\
\text { or the EU in at least seven out of eight recent years }\end{array}$ & \multirow{2}{*}{\begin{tabular}{c} 
Make work pay \\
\cline { 2 - 3 }
\end{tabular}} \\
\cline { 2 - 3 }
\end{tabular}


Appendix 3. contd...

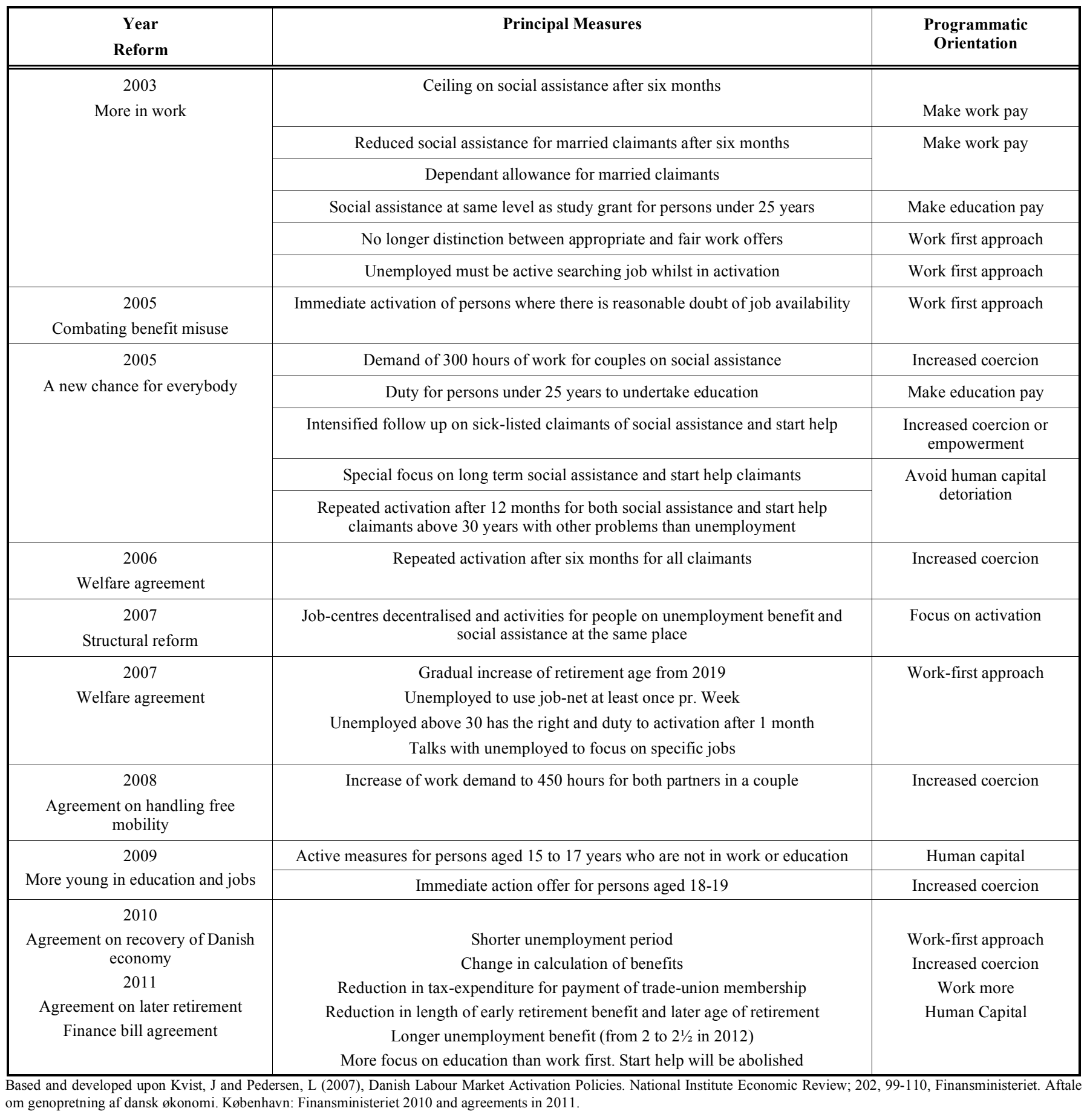

\section{CONFLICT OF INTEREST}

The authors confirm that this article content has no conflicts of interest.

\section{ACKNOWLEDGEMENT}

Declared none.

\section{REFERENCES}

[1] Greve B. What characterize the nordic welfare model. J Soc Sci 2007; 43: 43-51.
[2] Meidner R, Niklasson H. Arbetsmarknad och arbetsmarknadspolitik. Malmø, Sverige:Studentlitteratur 1970.

[3] Wilthagen T, Tros F. The concept of 'flexicurity': a new approach to regulating employment and labour markets. Trans 2002; 10: 16685.

[4] Marshall TH. Citizenship and social class. Cambridge: Cambridge University Press 1950.

[5] Mahoney J, Thelen K. Eds. Explaining institutional change: Ambiguity, agency and power. Cambridge: Cambridge University Press 2010

[6] Kvist J, Greve B. Has the Nordic welfare model been transformed? Soc Policy Admin 2011; 45(2); Greve B. Occupational welfarewinners and losers. Cheltenham: Edward Elgar 2007. 
[7] Scarpetta, S. Assessing the role of labour market policies and institutional setting on unemployment: a cross-country study. Econ Stud 1996; Paris: OECD. Nickell, S. Unemployment and Labour Market Rigidities: Europe versus North America. J Econ Perspect 1997; 11(3): 55-76; Martin, JP. What works among active labour market policies: Evidence from OECD countries experiences. OECD Economics Studies. Paris: OECD 2000; Martin, JP Grubb, D. What Works and for whom: A Review of OECD: countries experiences with active labour market policies. Swed Econ Pol Rev 2001; 8 (2): 9-56; OECD. Employment Outlook, 2005. Paris: OECD: Kluve, J. The effectiveness of European Active Labour Market Policy, IZA 2006. Dis Pap, no. 2018, Bonn: IZA; Card D, Kluve J, Weber A. Active Labour Market Policy Evaluations: A Meta-Analysis. The Econ J 2010; 120: F452-77.

[8] Nordlund, M. What works best when? The role of active labour market policy programmes in different business cycles. Int $\mathbf{J}$ Soc Welf 2010; 20: 43-54.

[9] Blanchard OJ, Summers LH. Hysteresis in unemployment. Eur Econ Rev 1987; 31: 288-95.

[10] Conley A. Childcare: welfare or investment? Int J Soc Welf 2010; 19: 173-81.

[11] Clasen J, Clegg D. Beyond activation: reforming unemployment protection systems in post-industrial labour markets. Eur Soc 2006; 8: 527-53.

[12] Serrano PA. Reshaping Welfare States: Activation regimes in Europe. Serrano AP, Magnusson L, Eds. Brussels: Peter Lang 2007.

[13] Dean H. The ethics of welfare-to-work. Policy Polit 2007; 35: 57389.

[14] Barbier JC, Ludwig-Mayerhofer, W. Introduction. The many worlds of activation. Eur Soc 2004; 6: 423-36.

[15] Gallie D, Paugam S. Welfare regimes and the experience of unemployment in Europe. Oxford: Oxford University Press 2000.

[16] Barbier JC, Ludwig-Mayerhofer W. Introduction. The many worlds of activation. Eur Soc 2004; 6: 425-6.

[17] Jørgensen H, Schulze M. Leaving the nordic path? The changing role of Danish trade Unions in the welfare Reform process. Soc Policy Admin 2011; 45: 206-19.

[18] OECD. Stat Extracts. Available at: http://stats.oecd.org

[19] Legatum Institute. The 2010 Legatum Prosperity Index. (www.prosperity.com) NEF. National accounts of well-being: bringing real wealth onto the balance sheet 2008. Available at: www.nationalaccountsofwellbeing.org.

[20] Greve, B. Velfærdssamfundet - en grundbog. København: Academica 2008.

[21] Danish Government. Denmarks National Reform Programme. First progress Report. København: Regeringen 2009.

[22] Beskaeftigelesesministriet. Available at: www.bm.dk

[23] Danish Government. The Danish reform strategy. København: Regeringen 2006; p.52.

[24] Scruggs L, Allan J. Welfare-state decommodification in 18 OECDcountries: a replication and revision. J Eur Soc Policy 2006; 16: 55 72.

[25] Nickell S. Unemployment and labour market rigidities: Europe versus North America. J Econ Perspect 1997; 11: 3.

[26] Martin JP. Measures of replacement rates for the purpose of international comparisons: A note. OECD Econ Stud 1996; 26: 99115 .

[27] Greve B. The hidden welfare state. Scandinavian Journal of Social Policy 1994; 4: 203-11; Howard C. The hidden welfare state. Taxexpenditures and social policy in the United States. Princeton: Princeton University Press 1997.

[28] Finansministeriet. Aftale om genopretning af dansk økonomi. København: Finansministeriet 2010.

[29] LO. Fremtidens arbejdsmarked - flere og bedre job. København: LO 2010.

[30] Jørgensen H, Schulze M. Leaving the Nordic Path? The changing role of danish trade unions in the welfare reform process. Soc Policy Admin 2011; 45: 206-19.

[31] Finansministeriet. Aftale om genopretning af dansk økonomi. København: Finansministeriet 2010.

[32] Borghouts I, Pas V. Labour market participation of the disabled: policies and practices in Europe. Eur J Soc Secur 2010; 12: 121-43.

[33] Cox RH. The social construction of an imperative. World Polit 2001; 53: 463-98.

[34] Cox RH. The Path-dependency of an Idea: Why Scandinavian welfare states remain distinct. Soc Policy Admin 2004; 38: 204-19.

[35] Greve B. The Nordic welfare states-revisited. Soc Policy Admin 2011; 45: 111-3.

[36] Jochem S. Nordic employment policies - Change and continuity before and during the crisis. Soc Policy Admin 2011; 45: 131-45. 